\title{
A FILOSOFIA COMO ESPIRITUALIDADE OU SINGULARIZAÇ̃̃o DO HOMEM EM KIERKEGAARD: O SI-MESMO (SELV) COMO ESPÍRITO (AAND)
}

\author{
[PHILOSOPHY AS SPIRITUALITY OR SINGULARIZATION OF MAN IN KIERKEGAARD: THE SELF \\ $(S E L V)$ AS SPIRIT $(A A N D)]$
}

Marcos Érico de Araújo Silva* Universidade Estadual do Rio grande do Norte, Brasil

RESUMO: O objetivo do presente trabalho é apresentar a perspectiva da filosofia de Kierkegaard como espiritualidade ou singularização do homem. Todo o projeto filosófico, edificado através do método da comunicação indireta, quer dizer, mediante o medium das obras pseudônimas e obras assinadas, são dialeticamente pensadas para tornar o homem atento, ou conduzi-lo ao vir-aser do que se é. Isto significa que a produção filosófica de Kierkegaard visa o homem que vive na não-verdade, na inautenticidade, na aespiritualidade para que, através dos pseudônimos, possa mobilizá-lo a pôr-se no movimento existencial de sua espiritualidade. Espiritualidade, aqui, significa apropriação do espírito, quer dizer, viver a existência desde a perspectiva ou abertura do espírito enquanto sintetização dos elementos constitutivos da ontologia do homem. Os chamados estádios existenciais só recobram sentido enquanto e como fundamentação filosófica do si-mesmo (Selv), quer dizer, do devir espiritual do homem. Esta singularização do homem, retirando-o da não-verdade ou a-espiritualidade (Selv como Individ), torna-o um Indivíduo Singular (Selv como den Enkelte).

PALAVRAS-CHAVE: Kierkegaard; Si-mesmo (Selv); Espírito (Aand)
ABSTRACT: The objective of this work is to present the perspective of Kierkegaard's philosophy as spirituality or singularization of men. The whole philosophical project, built through the method of indirect communication, i.e, using the medium of pseudonymous works and signed works, are dialectically designed to make man aware, or to lead him to the becoming of what it is. This means that Kierkegaard's philosophical production addresses the man who lives in the non-truth, inauthenticity, spiritlessness so that, through pseudonyms, he can mobilize him to put himself in the existential movement of his spirituality. Spirituality, here, means appropriation of the spirit, i.e, to live existence from the perspective or opening of the spirit as a synthesis of the constituent elements of man's ontology. The so-called existential stages only recover meaning as and as a philosophical foundation of the self (Selv), i.e, of the spiritual becoming of man. This singularization of man, removing him from untruth or spiritlessness (Selv as Individ), makes him a Singular Individual (Selv as den Enkelte).

KEYWORDS: Kierkegaard; Self (Selv); Spirit (Aand)

\section{I}

grande questão que deve ocupar a filosofia é compreender a articulação ou imbricação de homem e realidade. A filosofia, antes de tudo, originariamente, antes de ser teoria, ela é uma experiência (uma tonalidade afetiva, um páthos) de compreender a verdade do real, quer dizer, a relação homem e realidade

* Doutor em Filosofia pela UFPB-UFPE-UFRN, Professor do Departamento de Filosofia da Universidade Estadual do Rio grande do Norte-UERN, Campus Caicó - CaC, Professor permanente do Mestrado Profissional (PROF-FILO), Membro da Sociedade Brasileira de Estudos de Kierkegaard (SOBRESKI), Líder do Grupo de Pesquisa (DGP/CNPq) Núcleo de Estudos em Fenomenologia, Hermenêtica e Mística. E-mail: marcos_erico@yahoo.com.br 
desde a gênese de sua constituição, vendo, descrevendo o movimento da gênese do real, realizando-se em suas múltiplas concreções. Na disposição de querer explicar isto é que os filósofos criam os conceitos. Os conceitos são, pois, criados a partir da disposição filosófica de um páthos da distânica (Nietzsche), tornando possível compreender os fenômenos, o Real, desde sua gênese, de seu nascedouro. Quando estamos imersos nos 36 fenômenos, mergulhados num modo de ser já cristalizado, já sedimentado, já constituído, somos incapazes de qualquer postura crítica por não os compreender em sua verdade. Quando estamos colados, pregados, grudados em algo, paradoxalmente, justo essa excessiva proximidade, provoca a impossibilidade de medir, de dimensionar, enfim, de ver este algo como em realidade é. Não somos capazes de ver ou tematizar filosoficamente o fenômeno por não o ver ou descrevê-lo desde o movimento da gênese de sua criação ou constituição. Assim, decaindo do filosófico prevalece a erudição científica, a historiografia como informações sobre o Real, sobre os modos de existir como fenômenos entificados e estáticos enquanto dados previamente constituídos, já feitos e realizados. Só num páthos da distância é que torna possível entrar na gênese do fenômeno, para além de uma visão imediata, tomar a distância justa para poder medir, dimensionar e capturar a verdade do real.

A história da filosofia é um testemunho desta apreensão da verdade do real. Os filósofos criam conceitos, escrevem obras de pensamento desde esse páthos da distância para fornecer ao homem a explicação disto que está aí já consolidado, já sedimentado, já constituído. Mas a explicação do "já consolidado, já sedimentado, já constituído", quer dizer, do dado, não se detém em retratá-lo ou reproduzi-lo, mas em tornar visível a gênese de seu aparecer ${ }^{1}$. Esse "já" feito, pronto e acabado, fala desde a excessiva proximidade e não do páthos da distância que tornou possível a constituição e sedimentação disto que está aí. No cotidiano, no tempo e época atual, somos sempre envolvidos e engajados no já consolidado, já sedimentado, já constituído de uma visão de mundo, do Real. Nesta forma somos incapazes não só de compreender a verdade, que fundamenta esta sedimentação e cristalização, como nem sequer sentimos a necessidade de colocar em questão isto que está aí dado e consolidado. E, assim, não acontece a filosofia, ela não aparece, não se manifesta, pois é da natureza da filosofia não andar de mãos dadas com seu tempo e sua época.

Daí decorre que os homens são desde sempre amblíopes valorizando e reconhecendo apenas aquilo que sua falta de acuidade visual permite enxergar. No tempo e época atual, quer dizer, filosoficamente, em todo tempo e em toda época, os homens não têm olhos para ver, nem ouvidos para ouvir, nem tato para pegar a filosofia. Mas a cura disto é justo este con-tato com a filosofia. A importância da filosofia não está precisamente nisto? Todo filósofo verdadeiro não demonstrou o esforço de libertar o homem que vive, sem saber, escravizado? Do não-ser ao ser, das sombras à luz, da não-verdade à verdade, da não-liberdade à liberdade, do si mesmo ao si-mesmo, da inautenticidade à autenticidade, etc., enfim, a verdadeira filosofia é, nas palavras primorosas de Merleau-Ponty, "reaprender a ver o mundo" (MERLEAU-PONTY, 2014, p. 19). Não se pode, pois, esperar outra coisa da filosofia a não ser isto que dela se pode e deve esperar.

Como Kierkegaard contribui para a filosofia? Como ele compreende a relação homem e realidade? É preciso evidenciar, ou ao menos apontar, sobre a constituição primitiva ou trinitária do si-mesmo, do Selv. Para a finalidade deste artigo vamos tentar acenar para como Kierkegaard enquanto filósofo nos faz ver esta gênese da constituição do homem que fundamenta os diversos modos possíveis do homem vir-a-ser. Não tenho interesse em dar um tratamento historiográfico, erudito sobre a questão por uma dupla razão, a saber: na escrita dos escritos de Kierkegaard isto é combatido, e este modus operandi não conduz ao essencial em filosofia. Tentemos, então, acenar, entrar no fenômeno... Afinal de contas nós já sabemos o que é o homem!?! 


\section{II}

Esta IV edição do Colóquio Internacional Estética e Existência tem como temática a articulação de Filosofia e Espiritualidade ${ }^{2}$. Este texto, pois, enquadra-se na expectativa de cuidar disto, dando conta dessa articulação na filosofia de Kierkegaard. $\mathrm{O}$ "e" que dá um sentido de conexão e acréscimo no título da temática do evento deve ser, porém, lido, aqui, a partir de minha interpretação de Kierkegaard. E, assim, a compreensão da minha leitura interpretativa do "e" do título segue a lógica não do acréscimo de dois termos, mas como a conjugação de uma única realidade. Deste modo, "Filosofia $e$ Espiritualidade" deve ser lida ou compreendida na seguinte perspectiva, a saber, Filosofia como e enquanto Espiritualidade. Filosofia e espiritualidade são do mesmo espírito, da mesma estirpe, do mesmo pedigree.

Nesse sentido o título deste artigo justifica-se enquanto retrata o movimento da filosofia como espiritualidade: "A filosofia como espiritualidade ou singularização do homem em Kierkegaard”. Afirmar a ideia de filosofia como espiritualidade, em Kierkegaard, é apenas um outro nome para falar da essencialização, humanização, singularização do homem ou de sua interioridade. Toda a filosofia de Kierkegaard é um mostrar, um acenar, um jogar o leitor nas diversas possibilidades de existir e, assim, oferece-lhe uma compreensão de sua própria existência. Este movimento existencial do homem fazer-se homem é a espiritualidade, a singularização ou sintetização do homem. Mas o que fundamenta essa interpretação de compreender filosofia como espiritualidade? Resposta: o próprio Kierkegaard entende o espírito (Aand) como a determinação do homem, do si-mesmo. Em uma palavra: O homem é, na filosofia de Kierkegaard, determinado como espírito. Daí o subtítulo que aparece para precisar o sentido do título, a saber, "o si-mesmo (Selv) como espírito (Aand)". Kierkegaard compreende o homem como espírito, isto é, o homem é determinado pelo espírito ${ }^{3}$. Afirmar isto implica que o homem não está desde sempre pronto e acabado, quer dizer, determinado pelo espírito. $\mathrm{O}$ homem ou si-mesmo não é do âmbito do biológico. Ninguém, por assim dizer, nasce já um si-mesmo, mas precisa vir-a-ser. Assim, da mesma forma, na perspectiva cristã, a santidade não é biológica ou social, mas ela precisa vir-a-ser para aparecer, para existir. $\mathrm{O}$ homem, por assim dizer, mesmo sendo, não existe. A existência do homem só, na verdade, realmente existe, ou ganha consistência, à medida do espírito. O homem, todo e qualquer homem, inicialmente, imediatamente, não está determinado como espírito, mas está determinado pelos termos ou elementos heterogêneos que o constitui. Tudo isto é anúncio e prenúncio do caráter filosófico do pensamento kierkegaardiano.

Kierkegaard, de fato, pensa a realidade efetiva partindo, como informa Vigilius Haufniensis em $O$ conceito de angústia, do "real efetivo, para elevá-lo à idealidade" (KIERKEGAARD, 2010, p. 21). O princípio ou fundamento de sua filosofia não se pauta por um modelo ideal de homem que de algum modo seria apresentado como o critério de verdade de aplicação para todo e qualquer homem. Ao contrário, a arché da filosofia kierkegaardiana tem outro movimento, pois parte de situações existenciais descritas ou desenvolvidas existencialmente por indivíduos, através, muitas vezes, de pseudônimos. Nisto Kierkegaard quer destacar o caráter de luta, de saga do homem que está continuamente na busca de se determinar como espírito. Este método fenomenológico-existencial em que sempre descreve os fenômenos da existência, como, por exemplo, a angústia, a melancolia, o desespero, o amor, a fé, a alegria, o silêncio, servindo-se de pseudônimos e de personagens da literatura universal como arquétipos da existência, são analisados, não obstante sua riqueza e profundidade de análise, em virtude da fundamentação ontológica ou "estrutura primitiva" (KIERKEGAARD, 2008, p. 55) da constituição do homem, a saber, a estrutura sintética do si-mesmo. Sem visar existencialmente esta estrutura qualquer leitura possível de Kierkegaard torna-se frágil em sua consistência filosófica. É aqui que o pensamento de 
Kierkegaard ganha consistência e reconhecimento do ponto de vista filosófico. Sua fundamentação filosófica, quer dizer, partindo da "estrutura primitiva" de ter de ser um si-mesmo, Kierkegaard, em diversas obras, possibilita uma multiplicidade de análises fenomenológicas de modos de existir enquanto dinâmicas da determinação do homem como espírito, ou do fracasso existencial disto, a saber, o desespero.

A estrutura da produção filosófica kierkegaardiana, em sua dialética de produção pseudônima e verônima (obras assinadas), busca, pois, corresponder à própria realidade efetiva (Virkelighed) conferindo-lhe um sentido, quer dizer, pro-cura edificar uma estrutura de compreensão da imbricação de homem e realidade. Os pseudônimos representam modos de existências possíveis, e, portanto, eles operam como um espelho que reflete a imagem existencial daquele (a) leitor (a) que o contempla. Com efeito, as obras refletem distintos e diferenciados modos do homem se relacionar com a verdade, quer dizer, de se determinar ou não como espírito. Assim, a leitura de uma obra pseudônima não coincide propriamente com o pensamento de Kierkegaard, pois é preciso ter à vista o momento dialético em que ela se encontra e, portanto, representa. Ler, olhar para uma obra pseudônima é lançar o olhar para si mesmo, ou para um modo possível de existir, provocando uma crise, uma reavaliação crítica da própria escolha existencial sobre o modo como se vive a própria existência. Nesse sentido, pois, pseudô-nimo, em sentido grego, não comunica um nome falso, oposto ao verdadeiro, mas acena para um estar a caminho da verdade, do verdadeiro nome, de uma identidade, de um próprio. A produção pseudônima torna visível a dificuldade da liberação da identidade enquanto conquista e liberação da liberdade na busca da "verdade da apropriação" (KIERKEGAARD, 2013, p. 27). A Teoria dos Estádios Existenciais - estético, ético, religioso - enquanto fundamentação filosófica do simesmo (Selv) procura descrever o itinerário existencial da verdade da apropriação. Pseudônimo é um indivíduo singular, como o leitor (a), na busca de sua singularização, sintetização, espiritualidade. Isto acena para a compreensão de verdade na cena dramática da existência em que é preciso conquistá-la, apropriá-la, quer dizer, conquistar-se e apropriar-se determinando-se como espírito (Aand), quer dizer, autodeterminando-se ao esculpir a si-mesmo, o seu próprio, a sua identidade, concretizando uma possibilidade de poder ser para vir-a-ser.

$\mathrm{O}$ que funda esta estrutura de realidade é o conceito de homem, de si-mesmo $(S e l v)$. O homem é constituído de uma estrutura sintética, não dualista: corpo - espírito - alma ${ }^{4}$. Por essa razão, por força dessa estrutura, o homem possui e, ao mesmo tempo, paradoxalmente, não possui um si-mesmo. $\mathrm{O}$ homem enquanto não opera sua singularização não tem propriamente um si-mesmo, muito embora sua constituição ontológica possibilite o si-mesmo. O Selv (si mesmo) deve tornar-se Selv (si-mesmo). Ninguém nasce, pois, com um si-mesmo, mas o si-mesmo vem a ser. Em uma palavra: todos nascem com um si mesmo que precisam tornar-se si-mesmo. Mas só vem a ser (estádio ético-religioso) pelo fato de estruturalmente possuir um Selv ainda que não singularizado (estádio estético). A angústia é o elemento ou fenômeno que possibilita a liberdade do homem liberar sua identidade, tornando-se si-mesmo, um Indivíduo Singular (Selv como den Enkelte). A angústia, pois, conduz para a síntese, para a espiritualidade, para a sintetização ou singularização do homem. O desespero, ao contrário, é o fenômeno que impossibilita a síntese impedindo a singularização do simesmo. Aqui, temos, os diversos fenômenos da a-espiritualidade (Aandløsheden)5x.

No contexto de $\mathrm{Ou}$ isto, Ou aquilo de 1843 o desespero apresenta-se como último estádio dentro dos diversos estádios estéticos, precedido pelo penúltimo estádio, a saber, a melancolia. Os diversos estádios estéticos são caracterizados por diversos modos de existir nos quais o homem não se determina como espírito. $\mathrm{O}$ espírito, porém, está presente em virtude da constituição trinitária do si-mesmo. Mas sua presença não está ativa e desperta. Sua presença se faz sentir através da angústia ao acenar para a 
possibilidade de poder vir-a-ser. Ou, no penúltimo estádio, dentro do estádio estético, a melancolia é suscitada pelo espírito. No fenômeno da melancolia, o espírito, por assim dizer, se debate na prisão existencial em que vive, desejoso de alcançar a liberdade, determinando-se como espírito. O espírito quer ganhar uma forma, uma concreção. Escreve o Juiz Guilherme/Kierkegaard, na segunda parte de Ou isto, Ou aquilo:

O que é, então, a melancolia [Tungsind]? É a histeria do espírito. Na vida de um homem chega o momento em que a imediatez [vida estética!], por assim dizer, madurou, e na qual o espírito reclama uma forma superior na qual haverá de capturar-se a si mesmo como espírito. Como espírito imediato [vida estética], o homem se corresponde com a totalidade da vida terrestre, e então é como se o espírito quisesse subtrair-se a esta dispersão e concentrar-se e transfigurar-se em si mesmo; a personalidade quer tomar consciência de si em seu valor eterno [vida ética!]. Se isto não acontece, o movimento é interrompido, reprimido, então aparece a melancolia. É possível fazer muitas coisas para relegá-la ao esquecimento, alguém pode trabalhar, aplicar meios mais inocentes que os de Nero, porém continuará havendo melancolia. (KIERKEGAARD, 2007, p. 174175).

$\mathrm{Na}$ imediatez, característico da vida estética, a melancolia aparece como a histeria do espírito. A melancolia tem um aspecto positivo na medida em que as naturezas mais bem-dotadas também podem se deixar capturar por esta tonalidade afetiva. Como todo estado psicológico a melancolia tem sua ambiguidade: a existência é chacoalhada pela histeria do espírito, mas, ao mesmo tempo, não é dado o salto qualitativo para mudar de tonalidade afetiva. "A qualidade nova surge [...] com o salto, com a subitaneidade do enigmático" (KIERKEGAARD, 2010, p. 32). O salto seria para a vida ética em que o indivíduo se concentra, não mais em muitas possibilidades, mas numa única possibilidade, na escolha absoluta de seu si-mesmo eterno. Se o salto não é dado o indivíduo não alcança sua singularidade de fato e, assim, é tomado ou preso pela melancolia que sempre estará presente mesmo que se utilize de subterfúgios para dela se livrar. $\mathrm{O}$ desespero, aqui, em $\mathrm{Ou}$ isto, $\mathrm{Ou}$ aquilo, também tem sua ambiguidade psicológica. Por um lado, em sendo o último estádio dos estádios estéticos, impossibilita do homem tornar-se si-mesmo, conquistar sua singularidade, ao in-sistir em permanecer no pecado, em sua situação existencial. Por outro lado, paradoxalmente, na vivência do desespero, pode engendrar uma consciência qualitativa no sentido de não se desesperar apenas de algo, de alguma coisa, mas de se desesperar quanto a si mesmo no seu valor eterno. Aqui, paradoxalmente, o desespero pode ser tomado, escolhido como uma possibilidade para do desespero sair, saltar, ao escolher a simesmo em seu valor eterno. O Juiz Guilherme/Kierkegaard descreve isto nestes termos:

Não está longe o dia em que, acaso por um alto preço, aprenderemos que o verdadeiro ponto de partida para encontrar o absoluto não é a dúvida [Tvivl], mas o desespero [For-tvivl-else]. Porém, volto a minha categoria; não sou um lógico, tenho uma só, porém te asseguro que é a eleição de meu coração tanto como de meu pensamento, o desejo de minha alma e minha bem-aventurança - volto a importância da eleição. Ao escolher de maneira absoluta, escolho o desespero, e no desespero escolho o absoluto, pois eu mesmo sou o absoluto, ponho o absoluto e sou eu mesmo o absoluto; de modo totalmente idêntico posso dizer: escolho o absoluto que me escolhe a mim, ponho o absoluto que me põe a mim, e minha categoria da eleição careceria de verdade se não tivesse em conta esta segunda expressão, pois é justamente a identidade de ambas. Aquilo que escolho não é posto por mim, pois se não estivesse posto não poderia escolhê-lo; e, entretanto, se eu não o pusesse ao escolhê-lo, não o escolheria. É, pois se não fosse não poderia escolhê-lo; não é, pois só chega a ser em virtude de minha eleição, e de outro modo minha eleição seria uma ilusão. Porém, o que é, então, isto que 
escolho? Escolho por acaso isto ou aquilo? Não, pois escolho de maneira absoluta, e escolho de maneira absoluta precisamente porque não escolhi não escolher isto ou aquilo. Escolho o absoluto. E o que é o absoluto? Sou eu mesmo em meu valor eterno. Nunca posso escolher como o absoluto algo que não seja eu mesmo, pois se escolho alguma outra coisa, a escolho como algo finito, e, então, não a escolho de maneira absoluta. [...] Porém, o que é este "si-mesmo"? Se quiser mencionar seu primeiro momento, sua primeira expressão, responderia: é o mais abstrato de tudo, que é ademais, entretanto, o mais concreto de tudo - é a liberdade. (KIERKEGAARD, 2007, p. 194-195).

A citação é extensa e, portanto, demanda um maior trabalho de explicitação para justificá-la. Tem muita coisa que é possível explorar. Mas para os objetivos deste artigo será suficiente a caracterização geral do desespero, no contexto da concentração, por assim dizer, da consciência (o si mesmo) que se debate no último estádio estético e, partir disto, a possibilidade do salto, através da categoria da escolha, própria do estádio ético e da passagem para este estádio.

Um primeiro ponto a ser destacado é a contraposição crítica entre os conceitos de dúvida e desespero que a língua dinamarquesa ajuda a pensar. A palavra "desespero" (For-tvivl-else) já carrega em si a palavra "dúvida" (Tvivl). A dúvida é um procedimento mental, no âmbito do pensamento. $\mathrm{O}$ desespero é mais radical porque atinge e abate a totalidade da personalidade do homem. O desespero revela a existência do espírito e, portanto, enquanto possibilidade é o que há de mais grandioso no homem. Sua efetividade, porém, sua existência efetiva é a pior coisa que possa acontecer porque ele impossibilita a síntese do si-mesmo. O desespero, pois, é a enfermidade, a doença do si mesmo. Ao contrário de Descartes e de toda a modernidade, a dúvida, enquanto questão filosófica e toda operação que dela decorre, não possibilita a apropriação do absoluto. Apenas passando pelo desespero, quer dizer, através da vivência dos diversos estádios ou tonalidades afetivas dos estádios estéticos, chegando em seu ápice ou intensificação da consciência na imediatidade, é que a possibilidade do salto através da escolha do absoluto ao escolher a si mesmo em seu valor eterno, torna-se possível e real.

Outro ponto fundamental a ser destacado é que o Juiz Guilherme/Kierkegaard não é um lógico, quer dizer, não pensa a realidade, nem tem uma concepção de mundo e da personalidade do homem de forma abstrato-formal a partir de várias categorias lógicas. O pensador subjetivo é mais simples: tem apenas uma única categoria, a saber, a da escolha. E a escolha não disto ou daquilo, de infinitas possibilidades, próprio do esteta, mas, ao contrário, e, paradoxalmente, a escolha é do absoluto. O absoluto, porém, não o compreendendo abstratamente, em alguma categoria lógica ou metafísica, ou num arranjado erudito em algum parágrafo do Sistema. $\mathrm{O}$ absoluto, como consta na citação acima, "sou eu mesmo em meu valor eterno". E, aqui, aparece a dificuldade, muito própria e específica, quando envolve a existência e o existente. É o paradoxo! É a circularidade própria do pensar filosófico que se opõe ao tratamento linearizado, cronológico que rompe o círculo da arché. Esta escolha do absoluto ao escolher a mim mesmo em meu valor eterno é o si-mesmo singularizado, sintetizado, espiritualizado. É o Indivíduo Singular (Selv como den Enkelte), a subjetividade e interioridade ao conquistar a verdade da apropriação. Isto é a liberdade, quer dizer, o mais abstrato e o mais concreto! Pensar o si-mesmo, sem escamotear essa dificuldade, é a finalidade do pensador subjetivo. Concluo esta seção extraindo, da citação acima, essa passagem que explica o paradoxo da escolha. No meu compreender ela é muito luminosa para afastar toda obscuridade de compreensão voluntarista no pensamento kierkegaardiano:

Aquilo que escolho não é posto por mim, pois se não estivesse posto não poderia escolhê-lo; e entretanto, se eu não o pusesse ao escolhê-lo, não o escolheria. É, pois se não fosse não poderia escolhê-lo; não é, pois só chega a ser em virtude de 
minha eleição, e de outro modo minha eleição seria uma ilusão (KIERKEGAARD, 2007, p. 194, grifos nossos).

O homem faz a escolha, mas isto só é possível porque um horizonte (o espírito!) já lhe outorgou que isto apareça como uma possibilidade aprazível, desejável. No fundo não é o homem o dono e o senhor do processo de singularização, da passagem do si mesmo (Selv como Individ) para o si-mesmo (Selv como den Enkelte), mas é o próprio processo de singularização que é o protagonista, possibilitando-lhe que se singularize. A escolha só existe porque as possibilidades (ou a possibilidade) se apresentam como possíveis para o indivíduo. $\mathrm{O}$ homem realiza concretamente a escolha, e, se ele não a escolhe, não a pode realizar. Mas a de-cisão da escolha por uma possibilidade só é possível porque antes e originariamente um horizonte tornou uma dada possibilidade como mais própria e apropriada. A apropriação ou vivência da escolha é sempre uma tarefa, pois implica num modo de existir. Nesse sentido, não é o homem o dono e o senhor dessa ação, mas é essa ação que é a dona e a senhora do homem. Não é o homem que faz um modo de existência, mas é um modo de existência que faz do homem que é, o homem que vem a ser! Em um trabalho anterior tentei explicar essa dificuldade, esse paradoxo da escolha:

Na verdade e em verdade, quando o homem está imerso na dinâmica de sua singularização, quando ele é tomado e afetado por um modo de ser, um horizonte gratuitamente já aconteceu, já apareceu gratuitamente para ele, criando uma disposição, uma tonalidade afetiva (Stimmung, Stemning) que se abriu como um destinar-se de um destino que precisa vir-a-ser. Este destinar-se de um destino que tem de acontecer, de aparecer na concretude histórica do homem como um modo de existência, modulando sua existência desde agora e para o futuro, qualificando-a não mais impessoalmente [esteticamente!], mas desde um próprio, um si-mesmo (Selbst, Selv) não é obra, autoria, propriedade, causa do próprio homem. O homem, este si-mesmo (Selbst, Selv) que se singularizou não foi produto ou resultado de sua decisão, deliberação, vontade. Antes, mais originariamente, mais filosoficamente, foi a tonalidade afetiva (Stimmung, Stemning) que apareceu para ele, afetando-o, seduzindo-o, tomando-o, acenando para um destinar-se de um destino que se tornou um próprio fazendo-o, por assim dizer, exclamar em seu interior: "É isto que quero! É isto que busco! E isto que preciso ser para ser o que sou!". Portanto, é “isto", quer dizer, não uma coisa, mas a dinâmica da singularização do indivíduo, é "isto" que é o autor, o proprietário, a causa da apropriação da verdade enquanto um modo de ser que concretiza um destino, uma história, um modo de existência. Não é, portanto, o homem que toma a decisão pela sua singularização, mas antes e originariamente, nessa dimensão ontológica-existencial, é o próprio movimento de singularização quem possibilita o homem entrar, acolher, aceitar, decidir por singularizar-se. Não é o homem quem faz a singularização, mas é a singularização quem o faz! O homem não é a causa da ação, mas ele é per-feito por ela! (ARAÚJO SILVA, 2018, p. 5859 , grifos do autor).

Em uma palavra: a existência, como Kierkegaard gosta de expressar, é dom e tarefa (opgave), ou seja, inter-esse. Dom porque é pura gratuidade, dádiva, graça. Tarefa porque uma vez recebido o dom da vida é preciso fazer dela uma tarefa, um modo de existência para que possa vir-a ser o que deve ser. Tarefa de realizar e cumprir a graça da existência, de ter de vir-a-ser um si-mesmo, autenticamente, transparente para si mesmo. A tarefa, porém, por mais que bem cumprida seja, jamais deve obscurecer a graça, a gratuidade. Se isto acontecer é pura vaidade e odor fétido de desespero, do fracassar enquanto homem, por mais que realize grandes feitos no mundo, e viva sob holofotes da fama. 


\section{III}

O desespero (não angústia!) é designado por Kierkegaard, em 1849, de uma “doença para a morte". Mas, aqui, "doença”, "enfermidade”, da perspectiva filosófica, não se reduz a patologia, mas descreve a ontologia fenomenológica da não realização do tornar-se homem, quer dizer, o fracasso existencial de não se tornar homem. Desespero é, pois, o pecado, a insistência e persistência no mal, em não retomar ou redimir a existência. Pecado, pois, não tem conotação moral ou moralista, mas é um modo de existir, um posicionar-se distanciando-se da verdade. O pseudônimo AntiClimacus/Kierkegaard escreve:

O si-mesmo é a síntese [...], que se relaciona consigo mesma, e cuja tarefa consiste em chegar a ser si mesma [...]. Pelo contrário, se o si mesmo não chega a ser si-mesmo, então o temos desesperado, quer o saiba ou não. Portanto, o si mesmo não é si-mesmo enquanto não se faça si-mesmo, e o não ser si-mesmo é verdadeiramente o desespero (KIERKEGAARD, 2008, p. 51).

A tese de Kierkegaard gravita sempre tendo in mente o conceito de Selv (simesmo) ou den Enkelte (Indivíduo Singular). Todos os conceitos kierkegaardianos surgem, aparecem para configurar a explicação da passagem (Overgangen), da transição do homem ter de tornar-se homem, do si mesmo ter de tornar-se si-mesmo, quer dizer, na linguagem de Anti-Climacus/Kierkegaard: "Pois bem, chegar a ser simesmo significa que alguém se faz concreto" (KIERKEGAARD, 2008, p. 51). Inicialmente, originariamente, o si mesmo está na não-verdade, no pecado, no desespero, na imediatez. Precisa, pois, através da angústia, conquistar, apropriar-se de si-mesmo vivendo efetivamente sua possibilidade, concretizando seu modo de ser para que, assim, possa vir-a-ser o que é.

Afirmar que o si mesmo precisa vir-a-ser si-mesmo parece uma contradição, mas é apenas um paradoxo. Para livrar a aparente contradição e, então, podermos compreender o paradoxo enquanto paradoxo utilizo na tradução de Selv a diferenciação de si mesmo e si-mesmo. O "si mesmo" sem hifenização procura indicar ou capturar o fenômeno do homem na imediatidade, na não-verdade, na a-espiritualidade, disperso, fragmentado, rompido ou cor-rompido (vida de esteta), enquanto o "si-mesmo" hifenizado pro-cura revelar a relação, a singularização ou espiritualidade do homem, sua integração, articulação de sentido em sendo o que deveria ser e não poderia, por assim dizer, não ser (vida do ético-religioso).

A estrutura primitiva do homem é constituída de dois elementos heterogêneos como corpo e alma, temporalidade e eternidade, possibilidade e necessidade etc., sintetizados ou singularizados por um terceiro elemento conferindo uma unidade positiva. Quando o terceiro elemento não aparece, na forma desperta e lucidamente, temos uma unidade negativa. Aqui, no estádio estético, o indivíduo não operou sua singularização, pois vive na imediatidade e, portanto, o espírito está sonhando, quer dizer, está presente, mas dormindo, sem ser ativo, ou seja, não está determinado como e enquanto espírito. Vive a vida desde a perspectiva dos polos ou relatas de sua constituição primitiva, a saber, afirma a vida desde a corporeidade, sensibilidade, sensualidade em detrimento da vida anímica ou psíquica. Ou o fenômeno contrário, depositando a força no outro polo, a saber: afirma a vida desde a espiritualidade (neste caso, sempre falsa!), os valores do espírito em detrimento da corporeidade, sensibilidade, sensualidade. Uma vida sendo assim vivida e, portanto, desperdiçada, assemelha-se a um berimbau desarmado: possui os elementos constitutivos do instrumento musical, mas não sai som por não ter uma relação de tensão entre a beriba (madeira) e o aço.

A dificuldade encontra-se justamente em saber ver o fenômeno da compreensão de homem, quer dizer, possibilitar retirar um bom som deixando a coisa ser o que é em 
sua dinâmica existencial, isto é, tensionada, enredada. A Lógica, quer dizer, a estrutura do modo de pensar lógico-demonstrativo, neste âmbito da contingência, embaça o fenômeno e, portanto, só atrapalha por não ter o órgão apropriado para capturar o fenômeno. Falta acuidade de visão! A Lógica, crédula em seu modo de ser e pensar, a saber, lógico-demonstrativo, pensa o fenômeno analiticamente julgando que tal procedimento possibilita retirar um melhor som ao separar ou dividir em 1,2,3... os elementos constitutivos da existência: “o eins, zwei, drei sistemático [analítico!?] é uma forma abstrata que por isso também tem de ficar constrangida cada vez que há de ser aplicada ao concreto" (KIERKEGAARD, 2016, p. 74). Ocorre que tais elementos só existem existencialmente, quer dizer, enquanto acontecimento único, tensionado, enredado na existência, na vida. Um berimbau desarmado, embora possua todos os elementos constitutivos, não produz som. O som do berimbau decorre precisamente do berimbau "armado", quer dizer, só quando seus elementos constitutivos, a saber, a beriba e o aço estiverem tensionados possibilitando que o tocador, com a baqueta e o dobrão, ao "bater" no aço, possibilite que o som possa repercutir na caixa de ressonância da cabaça. Essa imagem nos introduz, nos joga dentro de todo e qualquer fenômeno existencial. Compreender o homem fora do tensionamento existencial de uma situação existencial para explorá-lo e dissecá-lo na "linguagem da abstração" é miopia, hipermetropia, ou astigmatismo da Lógica que deseja ver melhor ao subsumir a realidade efetiva às categorias lógica do pensamento. Em $O$ conceito de angústia o Vigilante da tradição filosófica, Vigilius Haufniensis/Kierkegaard escreve: "A perda, porém, salta aos olhos; pois nem a Lógica nem a realidade são bem servidas com isso" (KIERKEGAARD, 2010, p. 12). Este equívoco é combatido por Climacus/Kierkegaard no Pós-escrito designando de "linguagem da abstração" esse pensar da Lógica e, portanto, da metafísica tradicional, e nomeando de pensador objetivo aquele que equivocadamente a persegue.

$\mathrm{Na}$ linguagem da abstração nunca aparece propriamente aquilo que constitui a dificuldade da existência e do existente; e muito menos se explica a dificuldade. Justamente porque o pensamento abstrato é sub specie aeterni, ele prescinde do concreto, da temporalidade, do devir da existência, e da dificuldade do existente por este ser composição do eterno e do temporal, situada na existência. [...] $\mathrm{O}$ equívoco da abstração mostra-se justamente no que se refere a todas as questões da existência, das quais a abstração escamoteia a dificuldade, omitindo-a, e depois se gaba de ter explicado tudo. (KIERKEGAARD, 2016, p.13.14).

$\mathrm{Na}$ "linguagem da abstração" significa, pois, o modo de pensar da Lógica, da metafísica tradicional, da filosofia sistemática que, por sua própria natureza, obscurece o fenômeno da existência e do existente. $\mathrm{O}$ equívoco se dá em não mostrar a dificuldade da existência e do existente em virtude do tratamento formal e abstrato, e, portanto, deslocado de seu lugar, de seu próprio. Fora de seu elemento, da realidade efetiva, a existência e o existente, são tratados e transformados em proposições lógicas. Eis o grande equívoco da abstração! Com tal subterfúgio, "de modo docente" (KIERKEGAARD, 2013, p. 295) - recusado categoricamente por Kierkegaard e seus pseudônimos - omite-se eruditamente a dificuldade, gabando-se, porém, de ter, com isso, explicado com profundidade. O fenômeno da existência, quer dizer, os modos possíveis de existir, assim como o existente, a saber, o indivíduo que luta para conquistar sua subjetividade, sua interioridade, sua singularização ou espiritualidade não pode ser capturado pelo medium do sub especie aeterni. Analisar a existência e o existente da perspectiva da eternidade, da abstração, na forma de proposições ou categorias lógicas é promover uma separação, uma ruptura que desfigura e descaracteriza os fenômenos existenciais. Nas proposições lógicas a existência e o existente não existem! A "dificuldade" e o "equívoco" da "linguagem da abstração", 
denunciado por Climacus/Kierkegaard, de ter a pretensão de explicar, quando, na verdade, omite a dificuldade, revela a não possibilidade da Lógica, do pensamento abstrato explicar a existência e o existente. Climacus/Kierkegaard designa no Pósescrito de pensador objetivo esse docente, lógico ou metafísico, por utilizar da linguagem da abstração, e, em oposição a este, apresenta o pensador subjetivo por enfrentar a dificuldade da existência e do existente na linguagem apropriada.

O pensador subjetivo tem, portanto, ao mesmo tempo paixão estética e paixão ética, por meio do que se adquire a concreção. Todos os problemas existenciais são apaixonados, pois a existência, quando a gente se torna consciente dela, dá paixão. Pensar sobre eles de um modo que deixa de lado a paixão não é, de jeito nenhum, pensar sobre eles, é esquecer o ponto-chave de que se é, isto sim, um existente. [...] O pensador subjetivo não é um homem da ciência; ele é um artista. Existir é uma arte. [...]. A tarefa do pensador subjetivo é compreender-se a si mesmo na existência" (KIERKEGAARD, 2016, p. 68, negrito nosso, grifos do autor).

A "dificuldade" da existência e do existente que o pensador objetivo não tem paixão ou olhos para ver, consiste, justamente, por um lado, de que a existência sempre implica numa concreção, numa temporalidade, no estar sempre em devir, e, por outro lado, o existente, o si-mesmo "ser composição do eterno e do temporal, situada na existência". Essa composição do eterno e do temporal, do corpóreo e do psíquico sempre situada na existência é o sentido de homem ou si-mesmo em Kierkegaard. A existência do existente sempre se dá e se configura num modo de existir. Não há, não é possível existir uma compreensão de homem fora ou abstraída da escolha de uma possibilidade de poder-ser. A dificuldade, pois, colocada em evidência por Climacus/Kierkegaard, é compreender e explicar a existência do existente desde um modo de existência. Um modo de existência é possível de ser escolhido, ele se apresenta como uma possibilidade em virtude da composição sintética da constituição do homem. Mas é preciso precisar ou clarificar melhor essa compreensão: um modo de existência não é um estado de coisa dado, previamente constituído, existindo autonomamente fora do homem e que este escolheria obter como faz com objetos e coisas. O estádio estético, por exemplo, enquanto modo possível de existência, não tem o modo de ser de uma coisa, de um objeto. $\mathrm{O}$ homem que vive a existência estética, na verdade, não possui a vida estética, mas é possuída por ela! Sua escolha não se dá por um voluntarismo, mas escolhe a escolha ou possibilidade que antes misteriosamente o escolheu. Como a existência é já sempre vivida num modo de existência possível, as possibilidades aparecem já numa tonalidade afetiva (Stemning) tornando-as mais atrativa, mais sedutora de ser escolhida, de ser reconhecida. Nesta dinâmica, o elemento que possibilita o movimento existencial da possiblidade e escolha para o homem tornarse si-mesmo é a angústia. $O$ desespero também pode se fazer presente operando de forma distinta, como já vimos, abreviadamente.

Abrindo um parêntese. Toda a produção filosófica de Kierkegaard se ocupa em enfrentar essa dificuldade de explicar a existência e o existente. Em 1842, numa obra inacabada, Johannes Climacus ou É preciso duvidar de tudo, um ano depois de sua tese de doutorado e um ano antes da publicação de Ou isto, Ou aquilo de 1843 - obra na qual fala do estádio estético e do estádio ético - Kierkegaard já demonstra clareza sobre o problema que vai ocupar toda sua vida de filósofo. A obra descreve a vida de Johannes Climacus enquanto estudante e, portanto, trata da passagem existencial do não-filósofo para o filósofo. Na primeira parte descreve como Climacus começou a filosofar com a ajuda das concepções tradicionais, da metafísica tradicional. Sentimos a força da ironia ao acompanhar a tentativa de Climacus filosofar a partir da proposição De omnibus dubitandum est (É preciso duvidar de tudo). A dúvida era tomada como 
critério e princípio fundamental da filosofia moderna e de toda filosofia. Climacus desconfia disto uma vez que a dúvida é um princípio negativo, quer dizer, sua existência implica numa querela com um princípio anterior. Climacus ao colocar a dúvida em dúvida julga que a dignidade do princípio ou do começo em filosofia exigiria um princípio positivo. Assim aponta que o espanto dos gregos possui uma radicalidade maior e mais positividade que a dúvida dos modernos. Na segunda parte, inacabada, Climacus ousa filosofar por conta própria, já que se sente decepcionado pelo fato de que, paradoxalmente, embora a dúvida seja sempre louvada, nenhum escrito filosófico tratou das dificuldades e das vicissitudes daquele que se coloca no movimento da dúvida. A intuição de Climacus/Kierkegaard é de que a grande questão não está na proposição enquanto e como proposição (De omnibus dubitandum est), mas a dificuldade encontra-se na relação do indivíduo com a proposição. A grande questão não é a dúvida, mas com aquilo que possibilita ou permite que a dúvida possa existir, a saber, a consciência. Escreve o jovem Climacus/Kierkegaard:

Precisava descobrir a possibilidade ideal da dúvida na consciência. Esta última deveria, diga-se de passagem, permanecer sempre a mesma, por mais diversos que sejam os fenômenos que a ocasionassem, para que, sem se explicar pelo fenômeno, explica-se o efeito do fenômeno. Aquilo que suscitava no indivíduo a dúvida poderia ser tão diverso quanto se quisesse, mas, se não houvesse tal possibilidade no indivíduo, nada seria capaz de evocá-la. Dado que a diversidade de causas do fenômeno poderia ser uma contrariedade, a possibilidade teria de ser um todo essencial para a consciência humana. (KIERKEGAARD, 2003, p. 104105, grifos do autor, negrito nosso).

No embalo da dúvida a questão da consciência ou do si-mesmo fica obscurecida, escamoteada, omitida. A consciência ou si-mesmo tem, em si, a possibilidade ideal da dúvida, o que possibilita que, diante dos mais variados fenômenos, a dúvida possa tornar-se real, operativa. Por essa razão, Climacus/Kierkegaard abre caminho para o enfrentamento dessa questão, dessa dificuldade nas obras que se seguirão, após 1842 . Todo o corpus kierkegaardiano, portanto, visa dar corpo, concretude, densidade à questão da consciência ou do si-mesmo. Em Os conceitos fundamentais da metafísica: mundo, finitude, solidão, de 1930, o filósofo alemão Martin Heidegger, no meu entender, está visualizando a mesma questão, quando escreve no §6:

Não é por acaso que, com o advento da intensificação da tendência expressa de elevar a filosofia à categoria de uma ciência absoluta em Descartes, passa atuar ao mesmo tempo particularmente uma dubiedade característica da filosofia. Descartes teve a tendência fundamental de fazer da filosofia um conhecimento absoluto. Justamente em sua obra vemos algo notável. Aqui a filosofia começa com a dúvida e se dá como se tudo fosse colocado em questão. Mas apenas se dá como. O ser-aí, o eu (o ego) não é de modo algum colocado em questão. (HEIDEGGER, 2006, p. 25, grifos do autor).

Não vou explicitar a passagem de Heidegger. Trouxe apenas para registrar a importância de Kierkegaard na história da filosofia contemporânea. A crítica que Heidegger empreende aqui, a Descartes e a modernidade, de algum modo está motivada pela justificativa de que ele, Heidegger, realizou em Ser e tempo, ao colocar o Ser-aí em questão. No fôlego de nossa meditação quero mostrar que essa passagem de Heidegger mostra a sensibilidade e profundidade filosófica de Kierkegaard. Ambos estão vendo a mesma questão, o mesmo (Selbe)! Com isso, fecho o parêntese.

Retomemos! Antes do parêntese estava colocando em questão a dificuldade de que a existência e o existente são escamoteadas ou omitidas na linguagem da abstração. A existência implica sempre na temporalidade, em sempre estar em devir. A existência é sempre concreta, jamais abstrata. O existente, quer dizer, a consciência, o si-mesmo, 
sempre está na luta e labuta da vivência de uma situação existencial, fática, no mundo. A dificuldade de compreender o fenômeno da existência e do existente e, portanto, de uma consciência encarnada no mundo é pelo fato de sua constituição "ser composição do eterno e do temporal, situada na existência" (KIERKEGAARD, 2016, p.13). O existente justo por ser essa composição de elementos heterogêneos sente uma estranheza no mundo colocando em questão seu próprio modo de ser. Essa relação tensa e tensionada dessa composição do eterno e do temporal, do psíquico e do corpóreo engendra angústia, melancolia, desespero. Vigilius Haufniensis/Kierkegaard escreve: "Que a angústia apareça é aquilo ao redor do que tudo gira. O homem é uma síntese do psíquico e do corpóreo. Porém, uma síntese é inconcebível quando os dois termos não se põem de acordo num terceiro. Este terceiro é o espírito" (KIERKEGAARD, 2010, p 47). A angústia é o movimento existencial da possibilidade do homem vir-a-ser concreto. Isto é a liberdade. $\mathrm{O}$ homem, a consciência, o si-mesmo quando se faz concreto, é síntese do psíquico e do corpóreo graças ao espírito. Está escrito: “[...] só receberá subsistência graças ao espírito" (KIERKEGAARD, 2010, p 47). A dimensão corpórea e psíquica, da temporalidade e da eternidade só existem, só são possíveis de existir porque o espírito dá e garante a subsistência delas. É importante, pois, explicar como deve ser compreendida essa síntese que constitui o homem para que possa haver uma unidade positiva, um si-mesmo, e não uma unidade negativa. Quando Vigilius/Kierkegaard está definindo o homem como determinado pelo espírito está rejeitando a ideia metafísica de animalidade como perfazendo a essência do homem. $\mathrm{O}$ homem jamais foi ou é um animal porque ele deve ser determinado como espírito! Kierkegaard já bem cedo, pelo menos desde 1842, tem clareza de que o homem ou a "consciência é espírito" (KIERKEGAARD, 2003, p. 112) e que embora "[...] as determinações da reflexão [metafísica tradicional!] sejam sempre dicotômicas [...] as da consciência, ao contrário, são tricotômicas [...]" (KIERKEGAAD, 2003, p. 111-112), grifo do autor). É preciso, pois, explicar a síntese tricotômica que constitui a consciência para não recair, ou decair na dicotomia (dualidade!) amblíope de não enxergar o fenômeno em sua natureza arcaico-originária. Para explicar essa síntese tricotômica podemos nos servir da explicação de Gilvan Fogel que, em falando de realidade e perspectiva, enquanto uma relação arcaico-originária, está dizendo, ao meu ver, precisamente, o que Kierkegaard compreende por homem, consciência, si-mesmo.

Fala-se sempre de relação entre duas ou mais coisas ou termos. Com isso, pensa-
se o remetimento de um algo $A$ para um algo $B$, onde $A$ e $B$ já estão, previamente
dados ou constituídos. Entende-se este remetimento, esta referência (refero, trazer
ou levar de novo; reconduzir) como um processo de envio e de reenvio de $A$ para
$B$ ou de $B$ para $A$, ou ainda, simultânea e recíproca ou dialeticamente, de $A$ para $B$
e de $B$ para $A$. Esta recondução, esta mútua e recíproca referência - a relação -
pode ser bi- ou multipolar, mas tal movimento entre um e outro é sempre visto e
considerado desde os termos, a partir dos polos, a saber, dos relata. Segundo esse
modo de ver, o "entre" da relação constitui-se no espaço, na "extensão" que
separa uma ou mais coisas (termos) e que permite o movimento de andança de
um para outro polo. A verdade é que, à medida que assim se vê e se considera, a
relação mesma está encoberta, isto é, desvista e descuidada e, por isso, não
considerada no seu modo de ser própria. E como é este modo próprio de ser da
relação? (FOGEL, 2015, p. 70 , grifos do autor).

Esta explicação de Gilvan Fogel de uma estrutura arcaico-originária exonera a explicação lógica que não vê o fenômeno na circularidade da arché, em sua originariedade, mas explica como sendo ou possuindo status de a priori o que se dá apenas a posteriori. Tal procedimento do ver lógico não explica a dificuldade da experiência do fenômeno e, não obstante, se arvora em possuir a certeza da explicação.

O homem é constituído pelo corpóreo e o psíquico, pela temporalidade e a 
eternidade que subsistem, porém, graças a um terceiro. Quando a síntese acontece, ocorre a singularização, em virtude do terceiro elemento, engendrando uma unidade positiva. Temos, pois, um si-mesmo singularizado. Esta síntese é sempre na tensão existencial sendo sempre possível a "queda" e a "repetição", a retomada ou redenção, porque a existência é sempre no devir. É importante ver na estrutura constituinte do homem como sendo do âmbito arcaico-originário. Portanto, a dinâmica estrutural da síntese tem como protagonista ou como a priori o espírito, quando pensada na relação dos polos ou relatas do corpóreo e psíquico, ou como o a priori o instante, quando vista desde os polos ou relatas da temporalidade e eternidade. Os polos ou relatas são $a$ posteriori, quer dizer, eles se dão, ou só existem de fato por causa, em virtude, do terceiro, isto é, o espírito ou instante são o que dão "subsistência" aos polos heterogêneos. Exercendo a vigilância na tradição filosófica, Vigilius Haufniensis/Kierkegaard, alerta e sinaliza para o modo correto de ver na estrutura constituinte do si-mesmo (Selv) uma relação arcaico-originária ou, nas palavras de AntiClimacus/Kierkegaard, uma "estrutura primitiva” (KIERKEGAARD, 2008, p. 55): “[...] alma e corpo eram os dois momentos da síntese, e o espírito, o terceiro, porém de tal modo que só se podia falar em síntese quando se concebia o espírito" (KIERKEGAARD, 2010, p. 92, grifos nossos). O espírito ou instante são os a priori da fenomenologia ontológica-existencial do si-mesmo enquanto horizonte, abertura, espaço relacional, existencial, possibilitando a relação entre os relatas que se dão sempre a posteriori. Assim acontece a tensão enredada necessária entre o corpóreo e o psíquico no espírito, ou entre a temporalidade e a eternidade no instante. Isso implica em compreender que os polos ou relatas não existem como uma realidade de fato previamente constituída, mas são dimensões, modos de ser, de relacionar-se no mundo, graças ao espírito, seja singularizando-se (vida ético-religiosa), seja numa relação imediata (vida estética), o espírito sonhando. Quando a síntese não é estabelecida, a tensão é rompida, o homem fica "quebrado" e experimenta os diversos fenômenos existenciais como melancolia (Tungsind) e desespero (Fortvivlelse) que são tonalidades afetivas (Stemninger, Stimmungem) enquanto modos do espírito reivindicar ao homem a retomado da síntese, sua redenção. É importante apontar, ainda que não cabe neste artigo desenvolver, que, no processo de singularização, o homem experimenta tonalidades afetivas, experiências fenomenológicas-existenciais mais positivas, como alegria, silêncio, fé, amor, tematizadas por Kierkegaard em diversas obras.

O Indivíduo Singular (Selv como den Enkelte) não é, pois, nem corpóreo e nem psíquico, quer dizer, sua existência não é determinada pela corporeidade em contraposição da vida psíquica, ou vice-versa. Nesta perspectiva, quer dizer, deixando um polo ter primazia sobre o outro, o si mesmo não tem si-mesmo. A singularização ou espiritualidade da existência deve ser determinada pelo espírito. É justo o espírito o horizonte, o espaço relacional, a abertura existencial que torna possível existir a relação entre corpo e alma. A Lógica confunde essa compreensão de homem enquanto simesmo por pensar de forma linear e não na circularidade paradoxal, própria do pensamento filosófico autêntico. Vigilius Haufniensis/Kierkegaard escreve com uma grande clarividência fenomenológica: "Isto é um escândalo para o intelecto, ergo isto é um mito. Em compensação, ele mesmo inventa um mito que nega o salto e explana o círculo como uma linha reta, e aí tudo se passa naturalmente" (KIERKEGAARD, 2010, p. 34). A ametropia da Lógica só enxerga o espírito como resultado da relação corpo e alma: corpo + alma = espírito. Mas é só a partir do espírito que é possível falar na relação corpo-alma. Quando o espírito não está posto, singularizado, o si mesmo ainda não é si-mesmo, mas sempre é chamado a tornar-se. Deste modo, o si-mesmo como espírito conforma a filosofia kierkegaardiana como espiritualidade ou singularização: "O pensador subjetivo não é um homem da ciência; ele é um artista. Existir é uma arte" (KIERKEGAARD, 2016, p. 68). 
A chamada Teoria dos Estádios existenciais (estético, ético, ou religioso; estético, ou ético-religioso; estética, ética, religiosidade A ou B; etc.) só faz sentido da perspectiva filosófica enquanto um desdobramento da fundamentação filosófica do homem, quer dizer, do homem como si-mesmo. Os estádios existenciais são modos de existências em que revelam o devir espiritual ou existencial do homem. Os Estádios 48 Existenciais não falam de existências entificadas, cristalizadas, consolidadas, sedimentadas, mas de movimentos existenciais, da relação do homem com a verdade. Isto significa que só faz sentido falar em estádios - estético, ético, e religioso - em virtude e por força da "estrutura primitiva" ou trinitária da constituição do homem enquanto um si-mesmo. "Porque todo homem em sua estrutura primitiva está natural e cuidadosamente disposto para ser um si-mesmo" (KIERKEGAARD, 2008, p. 55). Identifiquei a "estrutura primitiva" do homem como sendo constituído de três elementos (corpo, espírito, alma; temporalidade, instante, eternidade) heterogêneos com a imagem do paradoxo do Deus Trinitário. Isto porque os três elementos que constitui primitivamente o homem, na verdade, não são três realidades entificadas, coisificadas, separadas, mas, ao contrário, modos de ser distintos de um único e mesmo fenômeno, acontecimento, sempre no e em devir. Imago Dei! Sim! Amém! Graças a Deus, ao Espírito! Mas que nada disso tenha o ranço da representação da metafísica tradicional - isso é religiosamente decisivo! Verdadeira piedade e não beatismo!

Um homem realizou a síntese, singularizou-se: tornou-se si-mesmo, um Indivíduo Singular, um Cavaleiro da fé. Este Indivíduo Singular não possui exteriormente nada que o distinga, nem a interioridade de sua personalidade revela nenhum sinal extraordinário de ter realizado o movimento de ser si-mesmo. Ele vive o extraordinário no ordinário de seu cotidiano. Sua existência é determinada pelo espírito! Não se destaca na multidão. Ele, porém, é o Indivíduo Singular, um si-mesmo, um Cavaleiro da fé, um homem do povo. Se tivermos a graça de conhecê-lo, de sermos apresentados, certamente exclamaríamos numa tonalidade afetiva de Temor e tremor:

"Meu Deus! Este homem que aqui está, é mesmo ele? Mas até tem ar de cobrador de impostos!" Não obstante, é mesmo ele. [...] Examinei-lhe a figura da cabeça aos pés, não fosse existir uma fissura através da qual o infinito espreitasse. Não! É solidamente maciço. O seu andar? É enérgico, pertence por inteiro à finitude; não é o andar de um burguês aperaltado que se passeia ao domingo à tarde em Fresberg; pisa a terra com maior segurança - pertence em tudo ao mundo, nenhum filisteu pequeno-burguês poderia pertencer-lhe mais. Nada há que me permita descobrir essa natureza peculiar e distinta pela qual reconhecemos o cavaleiro da infinitude. Alegra-se com tudo, participa em tudo e de cada vez que o que vemos participar no que é singular, tal sucede com a perseverança que caracteriza o homem terreno, cuja alma se apega firmemente a semelhantes coisas. Toma conta da sua actividade. Quando alguém assim o vê, haveria de pensar que é um escrivão que perdera a alma nos livros de escrita italiana, de tão exacto que é. Faz folga ao domingo. Vai à Igreja. Não há olhar celeste, nem sinal algum do incomensurável, que o traia; se não o conhecêssemos, seria impossível destacá-lo entre a restante multidão [...] No caminho, passa por umas obras e encontra outro homem. Falam por um instante os dois, levanta uma casa num ápice, dispõe de todas as forças para o fazer. O desconhecido deixa-o com o pensamento: de certeza que era um capitalista, ao passo que meu admirado cavaleiro pensa: se chegasse a sê-lo, lá me haveria de arranjar! Debruçado de uma janela aberta, contempla a praça onde vive, tudo o que aí se passa - um rato a esconder-se debaixo de uma tábua na sarjeta, as crianças a brincar - , tudo na existência o interessa [...] (KIERKEGAARD, 2009, p. 94-96).

Tinha muita razão Mestre Eckhart quando, compreendendo apropriadamente Deus, rezava para que Deus o livrasse de Deus, quer dizer, de suas representações. Em 
não ser neste espírito, quer dizer, querer explicar o si-mesmo, o Indivíduo Singular, fantasticamente, com beatismo, numa relação com Deus como se fôssemos anjos, espíritos puros, sem a concreção da existência "[...] é conversa fiada de seminarista" (KIERKEGAARD, 2013, p. 138).

\section{REFERÊNCIAS}

ARAÚJO SILVA, A superação da metafísica na filosofia de Kierkegaard e de Heidegger: as tonalidades afetivas (Stemninger, Stimmungem) como arché da filosofia, páthos do filosofar. São Paulo: LiberArs, 2018.

FOGEL, Gilvan. Homem, realidade, interpretação. Rio de Janeiro: Mauad X, 2015.

HEIDEGGER, Martin. Os conceitos fundamentais da metafísica: mundo, finitude, solidão. Tradução de Marcos Antonio Casanova. Rio de Janeiro: Forense universitária, 2006.

KIERKEGAARD, Søren. Johannes Climacus ou É preciso duvidar de tudo. Tradução de Sílvia Saviano Sampaio e Álvaro Luiz Montenegro Valls. Prefácios e notas de Jacques Lafarge. $1^{\text {a }}$ ed. São Paulo: Martins Fontes, 2003.

KIERKEGAARD, Søren. O lo uno o lo otro: un fragmento de vida II. Traducción de Darío Gonzáles. Madrid: Trotta, 2007.

KIERKEGAARD, Søren. La enfermedad mortal: una exposición Cristiano-psicológica para edificar y despertar. Traducción de Demetrio Gutiérrez Rivero. Madrid: Trotta, 2008.

KIERKEGAARD, Søren. Temor e tremor: lírica dialéctica. Tradução, introdução e notas de Elisabete M. de Sousa. Lisboa: Relógio D’Água Editores, 2009.

KIERKEGAARD, Søren. $O$ conceito de angústia: uma simples reflexão psicológicodemonstrativa direcionada ao problema dogmático do pecado hereditário de Vigilius Haufniensis. Tradução de Álvaro L. M. Valls. Petrópolis: Vozes; Bragança Paulista: Editora Universitária São Francisco, 2010.

KIERKEGAARD, Søren. Pós-escrito conclusivo não científico às migalhas filosóficas: coletânea mímicopatético-dialética, contribuição existencial, por Johannes Climacus. Vol. 1. Tradução de Álvaro Luiz Montenegro Valls e Marília Murta de Almeida. Petrópolis: Vozes; Bragança Paulista: Editora Universitária São Francisco, 2013.

KIERKEGAARD, Søren. Pós-escrito conclusivo não científico às migalhas filosóficas: coletânea mímico-patético-dialética, contribuição existencial, por Johannes Climacus. Vol. 2. Tradução de Álvaro Luiz Montenegro Valls e Marília Murta de Almeida. Petrópolis: Vozes; Bragança Paulista: Editora Universitária São Francisco, 2016.

MERLEAU-PONTY, Maurice. Fenomenologia da percepção. Tradução de Carlos Alberto Ribeiro de Moura. São Paulo: Martins Fontes, 2014.

\section{Notas}

1 Estudar ou lecionar filosofia é tornar visível isto. É um procedimento de entrar no fenômeno e experimentar a gênese de sua constituição e posteriores desdobramentos, concreções. A filosofia verdadeira se ocupa do exercício do filosofar, quer dizer, do mostrar o fenômeno da coisa mesma da filosofia vindo a ser, em seu aparecer, ganhando, com isto, concreção e densidade. O contrário deste movimento é o predomínio do enciclopedismo, da historiografia, dos -ismos. Este procedimento mata a filosofia, ao sepultar o filosofar, num procedimento anti-filosófico por uma voracidade de muitas informações e autores que informam sobre a coisa sem mostrar, porém, o decisivo, a saber, o movimento genesíaco, arcaico-originário de sua constituição. Estudar e lecionar filosofia não é reproduzir informações, mas, antes, é tornar visível o fenômeno do que está em questão na informação, no dado. Não é, pois, catalogar e reproduzir dados e informações, mas saber dia-logar com essas informações ao entrar em diálogo com o filósofo estudado, cofazendo e co-pensando o dado, o pensado. Non multa, sed multum!

$2 \mathrm{O}$ presente artigo, numa versão mais reduzida, foi apresentado neste evento. Para a presente 
publicação o texto foi reelaborado e ampliado.

3 Esta formulação aparece já em Ou isto, Ou aquilo de 1843, em sua segunda parte, quando o Juiz Guilherme ("B"), escrevendo para o jovem esteta ("A"), acentua que, não obstante todas "[...] as diferenças dentro do estético, todos os estádios [no estético] tem essencialmente algo em comum, a saber, que o espírito não está determinado como espírito, mas que está determinado de maneira imediata" (KIERKEGAARD, 2007, p. 168, grifo nosso). Também em $O$ conceito de angústia de 1844 a formulação que define o homem em Kierkegaard, reaparece, perfazendo, assim, a direção da perspectiva da compreensão de homem: "Na inocência, o homem não é meramente um animal. De resto, se o fosse a qualquer momento de sua vida, jamais conseguiria chegar a ser homem. $\mathrm{O}$ espírito está, pois, presente, mas como espírito imediato, sonhando. [...] nem tampouco o homem pode mergulhar no vegetativo, de jeito nenhum, pois ele está determinado, afinal, enquanto espírito. (KIERKEGAARD, 2010, p. 47, grifo nosso). O homem jamais é ou foi animal! O homem é espírito e está determinado como espírito!

4 Mais adiante tentarei explicar essa estrutura. Aqui, porém, é importante anunciar que esses elementos (corpo, espírito, alma) não são realidades entificadas, nem são compreendidos como aglutinação, somatório e, assim, o espírito (Aand) não pode ser entendido como resultado da relação corpo-alma. Só existe a relação corpo-alma por causa do espírito. Portanto, é o espírito que instaura a relação e não a relação que engendraria o espírito! Com efeito, o homem ou si-mesmo enquanto síntese instaurada e constituída pelo espírito revela que o homem (corpo, espírito, alma) não é ou são coisas, mas modos de ser, de existir.

5 Descrever o fenômeno da a-espiritualidade não é possível de ser realizado neste artigo. Mas fica a provocação, a chaga aberta que este artigo abriu no espírito do autor. É interessante examinar a diferenciação entre os fenômenos da ausência de espírito (Aandsfravarelse) e o da a-espiritualidade ou insensibilidade espiritual (Aandløsheden). No contexto de $O$ conceito de angústia o primeiro fenômeno, o da ausência de espírito (Aandsfravarelse), ocorre no paganismo, e, o fenômeno da a-espiritualidade (Aandløsheden) no cristianismo, melhor, na cristandade, e na modernidade filosófica. Vigilius Haufniensis/Kierkegaard situa o fenômeno da ausência de espírito (Aandsfravcerelse) do paganismo grego, numa melhor situação em relação ao fenômeno da a-espiritualidade ou insensibilidade espiritual (Aandløsheden) da cristandade e da metafísica tradicional. Escreve o Vigilante da tradição filosófica: "[...] a diferença entre o paganismo e a falta de espiritualidade consiste em que aquele [paganismo; Aands-fravorelse] se dirige para o espírito, e essa [falta de espiritualidade; Aand-løsheden] se afasta do espírito" (KIERKEGAARD, 2010, p. 102). 